\title{
A Multi-Functional Layouts Model for Enhancing Affordable Design in Residential Buildings in Amman City
}

\author{
Wael W. Al-Azhari \\ Department of Architecture Engineering, School of Engineering, the University of Jordan.
}

\begin{abstract}
An increasing number of people in Amman city are living in apartment buildings. During the late 1970s, the apartment building developed as a residential building type in Amman city. By the 1990s, it became the main building type. The study explores the increasing demand of the small apartments in residential buildings in Amman city to provide a new model of multi-function apartment with cheap price, which can be affordable to low-income people. A review of the literature revealed of four apartments types in Amman city by which the study is integrated into design of a new multifunction apartment prototype within existing regulations that can help utilize building technology, conserve energy, reduce overall apartment prices, and increase the overall quality of life. The multi-function apartment prototype suggested as an answer to the high residential apartments prices in Amman city. The study starts by evaluate the current situation of the available apartments on market. It depends on certain parameters, which are: apartment type, apartment capacity, apartment price, energy demand, and the building technology. A base model is proposed as a case of a multi-function apartment that adapts with the current Amman's city style and to realize the Jordanian market needs.
\end{abstract}

Keywords: Residential Apartments, Multi-Function Layouts, Building Technology.

\section{INTRODUCTION}

In Jordan, the annual growth of population is $2.8 \%$. Apartment building had become the most dominant housing type to meet new demands on housing needs with rapid urbanization and high population density. A high percentage of population lives in apartment buildings especially in highdensity cities, i.e. Amman, Irbid, and Zarqa. Over the 20042015 period the construction sector produced over 1.1 million units, reaching over 2.3 million units in 2015, far exceeding Government estimates by an impressive 800,000 more than predicted, which is an indication of intense building activity (World Bank Group, 2018).

Up to the 1970s, it was very common for people in Amman city to build freestanding, one-story, single-family houses. Such houses, most often, would later be expanded vertically to reach two or three stories. The owner of the house would build these additions for the use of his/ her children (usually sons) after they grow up and have their own families, or to rent out as a source of additional income (Al-Asad, 2004).

There are about 112,241 residential apartments in the urban areas to serve about $82.6 \%$ of the total population. Number of residential apartment buildings in Amman city is about 65,557 units, 11,065 units exist in Irbid city and 19,678 units exist in Zarqa city (DoS, 2018)

Current zoning regulations for apartment buildings allow the construction of four stories. However, if the building is located on a sloping site and a street borders the higher part of the site, one may have as many stories as the slope allows. The only requirement is that the building does not include more than four stories along its higher part. The construction of apartment buildings is allowed in most parts of Amman city, and is prohibited only in a very limited number of areas in the city. Not surprisingly, land values in such areas are prohibitively high. Simple economics therefore have resulted in the apartment building taking over the city. Meanwhile, the single-family structure now has become beyond the reach of the vast majority of Amman's city residents, including many well-off ones (Al-Asad, 2004).

\section{LITERATURE REVIEW}

\subsection{Apartment types in Jordan}

During the last decade and because of the large increasing in population, there was a large increase in multi-apartment building construction in Amman city (Beithou and others, 2011). Residential apartments had been tremendous on Amman city. It definitely had raised the density of habitation in the city. The common four-story apartment building, which usually includes two apartments on each floor, will have about eight families inhabiting it. Of course, there are the more luxurious apartment buildings with one apartment per floor, but there are also apartment buildings types that have additional living units because of their location on a sloping site and other parameters. Below is a summary of these types:

\subsubsection{Full floor apartment (Type I)}

luxurious apartment buildings with one apartment per floor with average area 200 square meter, established due to limited land size, it have about four families inhabiting, Figure 1 and Figure 2. 


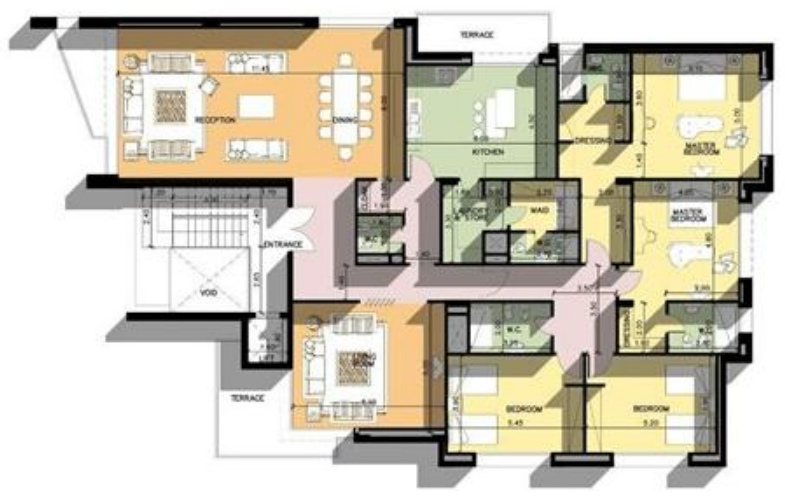

Figure 1. Typical Floor Plan, Type I Apartment.

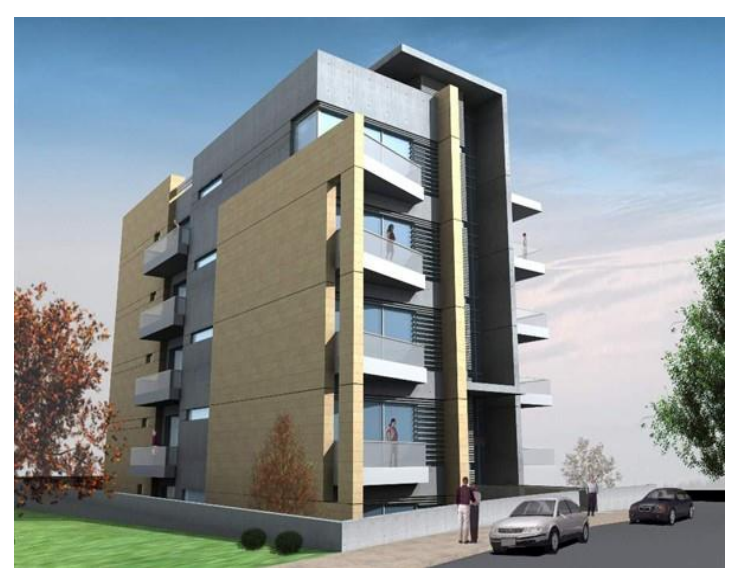

Figure 2. Perspective, Type I Apartment.

\subsubsection{Typical apartment (Type II)}

Typical four-story apartment building, which usually includes two apartments on each floor, with average area 90-150 square meter, it have about eight families inhabiting, Figure 3 and Figure 4.

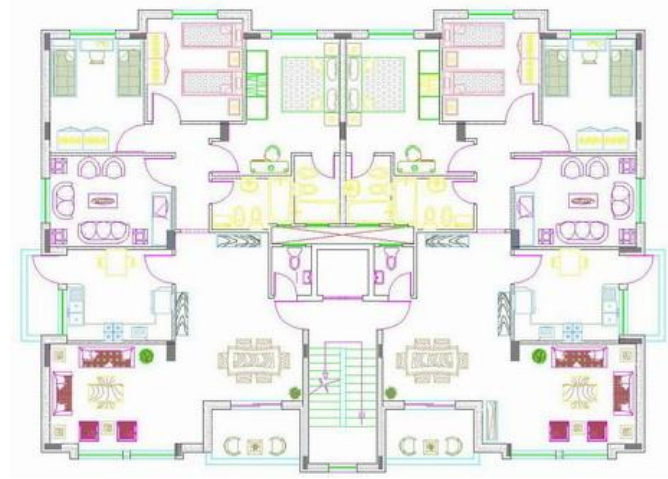

Figure 3. Typical Floor Plan, Type II Apartment.

\subsubsection{Crowded apartment (Type III)}

Apartment Building consist three or more flats in each floor, with different areas, usually locate located on a sloping site

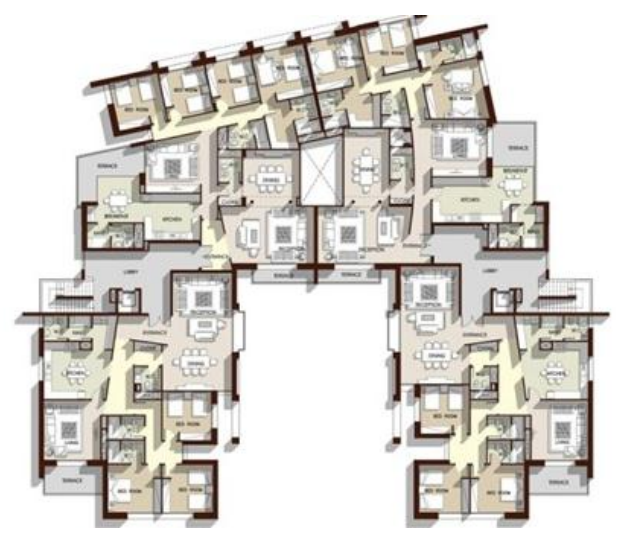

Figure 5. Typical Floor Plan, Type III Apartment.

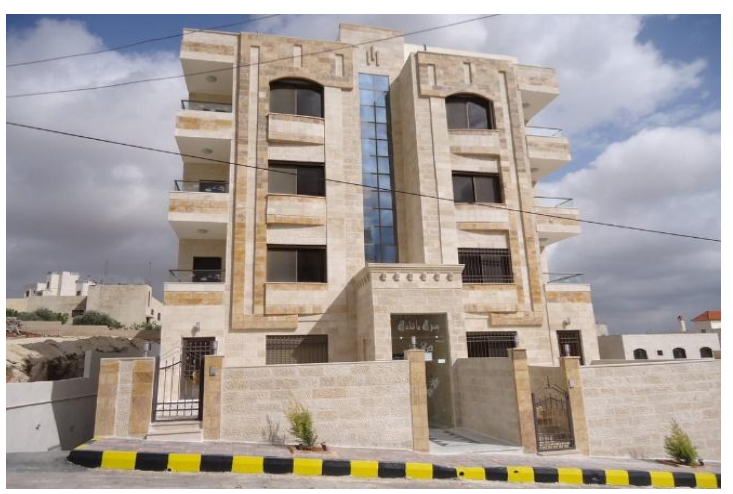

Figure 4. Perspective, Type II Apartment.

and a street borders the higher part of the site, one may have as many stories as the slope allows. It has about twelve families inhabiting, Figure 5 and Figure 6.

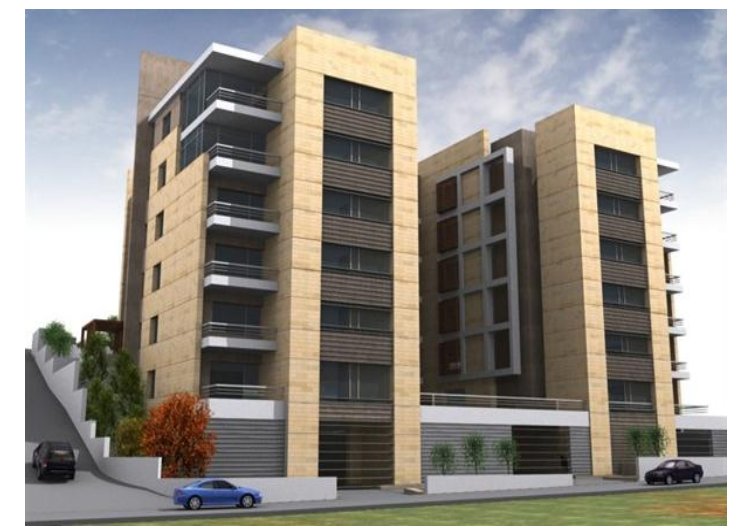

Figure 6. Perspective, Type III Apartment. 


\subsubsection{Compound apartment (type IV)}

Set of building consist (more than 50 apartments) usually detached with each other with public space in the middle contain services like; parking, public garden, and maybe shared swimming pools, Figure 7.

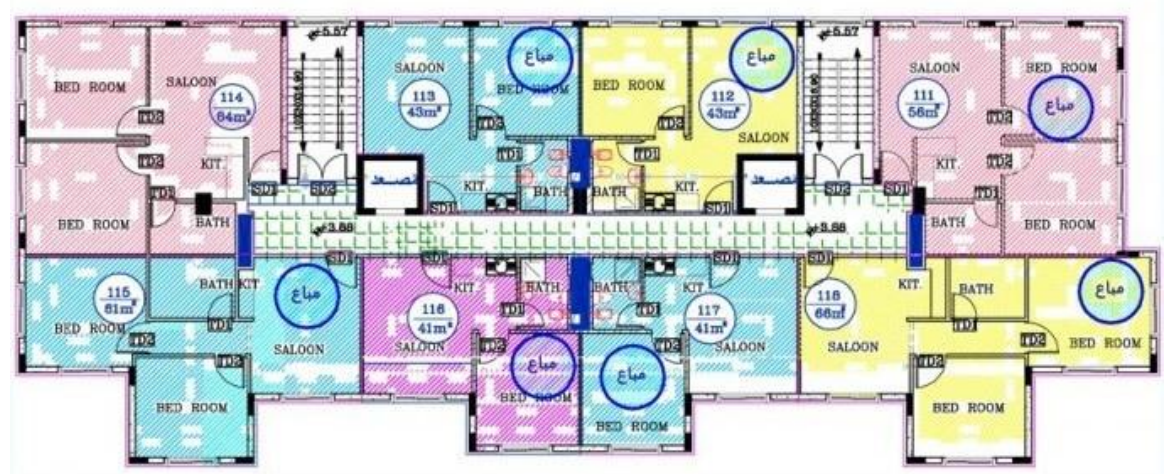

Figure 7. Typical Floor Plan, Type IV Apartment.

\subsection{Multi-Function apartment's benefits}

Many homeowners agree that living in a larger home leads to greater stress. From cleaning, maintenance, furnishing, outdoor home upkeep and the cost to run all of that, can lead to a home that is stressful. Downsizing your home can be the first step to a minimal and streamlined life. You will be surprised how reducing your daily chores and maintenance will free up your time for leisure activities, spending time with your family, getting more rest, and maybe loving your home more than loathing it (Friedman, 2006). There are many benefits for living in small apartment, such as:

1. Save money on frivolous living, and establish it with affordable price; the more space you have the more area you feel like you need to fill.

2. A smaller home means often leads to strong social relationship.

Many homeowners agree that smaller homes enable the family to bond and work together. Smaller homes create an environment where family members get organized and can compromise over living arrangements.

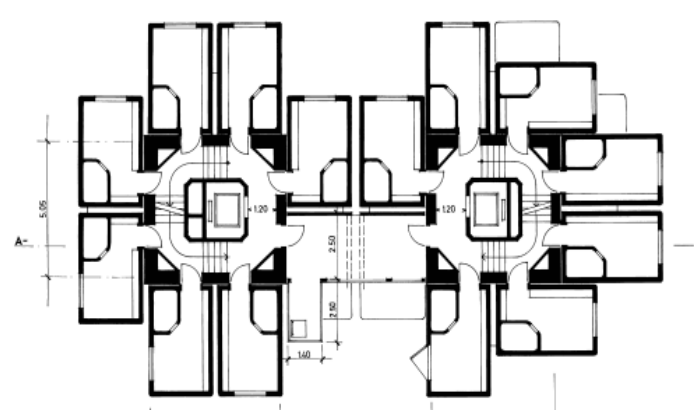

Figure 8. Typical plan of Nakagin Capsule Tower.
3. Reduction in the amount of energy consumed.

About $60 \%$ of the energy consumed within a building goes for heating and cooling purposes (Jaber, 2002). Smaller homes gave an additional benefit of reducing total family's carbon footprint meanwhile enjoying with a lower energy bill in the warmer and cooler months (Weinzettel, 2011).

\subsection{Case Studies}

\subsubsection{Case Study No.1: Nakagin Capsule Tower, Tokyo,} Japan.

This mix-use building consisting of 144 cubic pods distributed on 13 story. It was built in 1972 as a rare example of the metabolism movement in Japanese architecture. This prized module-based designs which individual units could be replaced. Each of the 144 Nakagin capsules is its own $(2.5 * 4.0 * 2.5)$ meters apartment, designed for single salary men. The units are equipped with a stove, refrigerator, TV, reel-to-reel tape deck, and telephone. The bathroom, which resembles an airplane lavatory, is three steps from the bed. A table folds down from the wall for dining and work (Lin, 2011), Figure 8 and Figure 9.

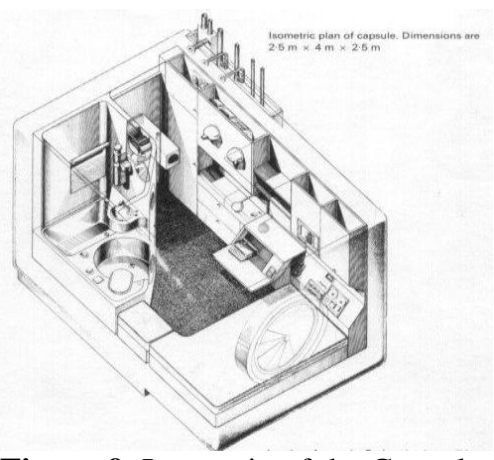

Figure 9. Isometric of the Capsule. 


\subsubsection{Case Study No.2: Small Multi-Function Apartment,} Tel-Aviv.

Designing and decorating small spaces can often be a hassle that demands plenty of care and attention. However, with a hint of innovation and smart, space-conscious solutions you can transform even the tiniest of apartments into a luxurious little hub. Located in Nachmani Street, Tel Aviv, this elegant little apartment occupies a space of just 50 square meters (Nothingam, 2014), Figure 10.

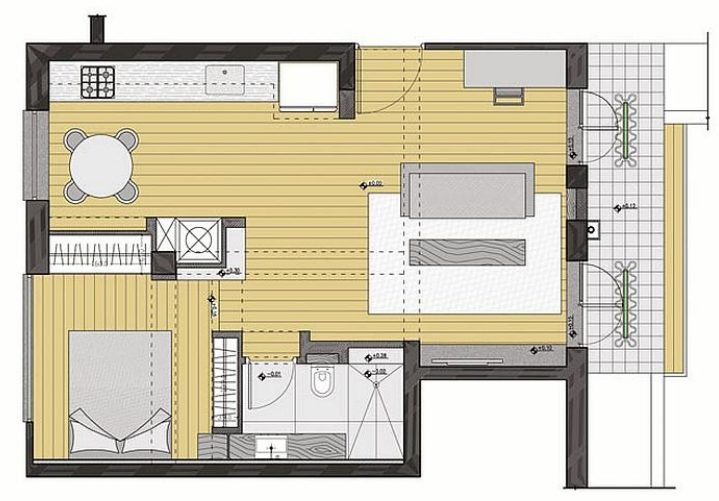

Figure 10. Typical Floor Plan, Nachmani Street, Tel Aviv Apartment.

Source: (Nothingam, 2014)

2.3.3. Case Study No.3: Vertical Garden and Sleeping Pod Feature in Small Madrid Apartment, Spain.

The area is 46 square meter. The original layout of the apartment had a double east-west orientation, but the excessive compartmentalization of the spaces obstructed the cross-ventilation in the bedrooms, which meant that the westfacing spaces were excessively hot in summer.

To address the issues, the interior space was redistributed to create an ample living area, open on both east and west sides of the building, which allows air to circulate during the hot summer months (Morris, 2019), Figure 11.

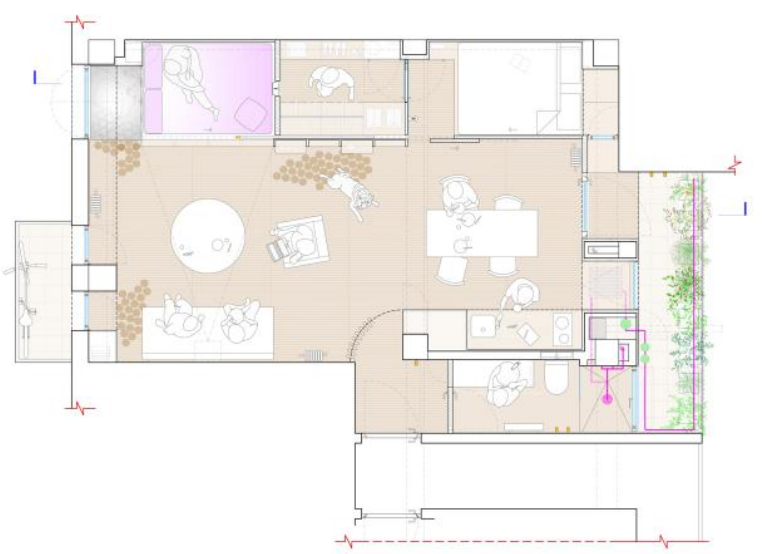

Figure 11. Typical Floor Plan, Madrid Apartment.

Source: (Morris, 2019)
2.3.4. Case Study No.4: Multi-Generation Apartment House Changing With The Family, Singapore.

This contemporary home employs the traditional Asian concept of multi-generation living in a modern residential structure. Which care for different needs of each inhabitant and to unify the family in a set of common spaces? The three story Apartment House project in Singapore is not only a family fortress, but also an adaptable dwelling that can easily be expanded or changed, according to each generation's needs (Crook, 2016), Figure 12.

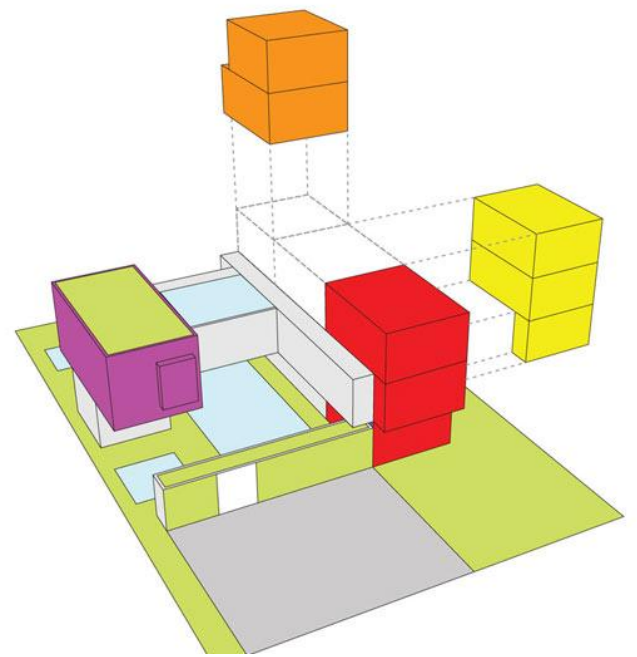

Figure 12. 3D Model Shows Stages of the House Growth. Source: (Crook, 2016)

\section{RESEARCH METHOD}

\subsection{Research subject}

There is a need to find ways of improving the apartment building in Amman city especially that $82.6 \%$ of the total population live in these apartments (DoS, 2018). This study aims to design a multi-function apartment model comply with Amman city life requirements, and compered it then with the typical apartment type II which is the most common type in Amman city.

\subsection{Development of a measuring tool}

\subsubsection{Apartment areas, capacity, and adaptation}

The average areas of these apartments range from $90 \mathrm{~m} 2$ to $150 \mathrm{~m} 2$, and the personal space (occupation rate) in these apartments is 0.23 person $/ \mathrm{m} 2$, depending on the fact that the average household size in Jordan is 2.8 person (Al Momani and Ali, 2008). The average family member is five members, and the consumption average monthly of electricity accounted for 14.5 JD (DoS, 2018), most of the apartment buildings built in one stage with no development after construction period.

\subsubsection{Energy demand}

Jordan is a developing non-oil producing country located in the Middle East. Jordan imports $95 \%$ of its energy from 
neighboring countries. In general, large cities are comprised of high-rise and multi-apartment buildings, where the application of passive heating and cooling techniques is a difficult task. Energy consumption for residential purposes accounted for $18 \%$ of the total consumed energy in 1999. By 2009 , energy consumption for the residential sector jumped to $30 \%$, about $60 \%$ of the energy consumed within a building goes for heating and cooling purposes (Jaber, 2002). During the last decade and as a result of the large increase in population, there was a large increase in multi-apartment building construction in Amman. A changing climate requiring more heating and cooling and an improved standard of living, have led to huge increases in energy consumption, raising the need to address concerns of a continuously increasing demand for energy (Beithou and others, 2011).

\subsubsection{Technology used (form \& material)}

Apartment buildings form the most frequently repeated, reduplicated building's type in Amman- Jordan, with a huge lack in the aesthetic aspects or understanding of the architectural references, where the common practice usually combines a wide array of decorative techniques and elements taken from different periods of historical styles. which doesn't reflect a sense of place or time, nor the technologies or building skills that have been reached in the place these buildings were constructed in, and doesn't show the development that have been witnessed in the contemporary architecture around the world or in this region. While Construction Materials that used in apartment buildings are brick, stone, concrete and insulation with external or internal plaster (Al Momani and Ali, 2008), Table 1.

Table 1. Summary of Typical Apartment (type II) Studying Properties.

Typical apartment (type II)

\begin{tabular}{|c|c|}
\hline Average Apartment Area & $90-150$ square meters \\
\hline Apartment Capacity & 1 family $\backslash$ average 5 members \\
\hline Apartment Adaptation & $\begin{array}{l}\text { No development availability after } \\
\text { construction period }\end{array}$ \\
\hline Price (average) & $50,000-100,000 \mathrm{JOD}$ \\
\hline $\begin{array}{l}\text { Technology Used } \\
\text { (building form and } \\
\text { material) }\end{array}$ & $\begin{array}{l}\text { Current apartment shows lack in the } \\
\text { aesthetic and technological aspects }\end{array}$ \\
\hline
\end{tabular}

3.3. Development of plans for enhancing Intelligent Multifunctional solutions

\subsubsection{Concept}

It is not always an easy thing to tell the difference between livings, dead, and non-living things. Prior to the 1600's many people believed that nonliving things could spontaneously turn into living things. For example, it was believed that piles of straw could turn into mice. That is obviously not the case. There are some very general rules to follow when trying to decide if something is living, dead, or non-living.

The concept of multi-function apartment considers it as a living creature and living things have a variety of common characteristics, i.e. organization, homeostasis, adaptation, reproduction and heredity, growth and development, energy acquisition and release, detection and response to stimuli and interactions (Bergman, 2020), Figure 13.

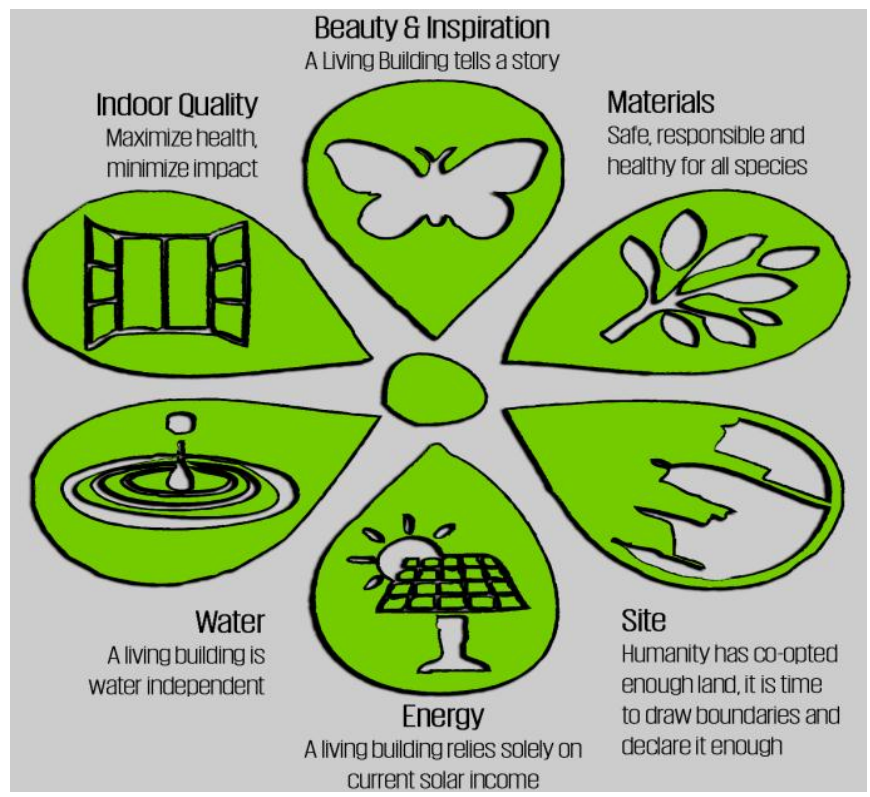

Figure 13. The Multi-Function Apartment as a Living Creature.

Source: (Bergman, 2020)

After understanding these characteristics, we are going to make them the main components of our multi-function apartment design through translating them to real and unique elements or architecture vocabulary of the apartment. Without neglecting, the needs to be integrated across several mature disciplines and design objectives. Comparing it after that with previous Amman apartments and cases to create multifunction apartment

\subsubsection{Site selection criteria and land properties}

The criteria for selecting the site were:

- Avoid using sites that have special value like agricultural land, cultural sites, wetlands, habitats of endangered species etc.

- Ensure that the design and construction does not result in any damage to the vegetation or their ability to survive.

- The comprehensive transportation plan for the site should be easy and clean, taking into consideration cleaner transportation options and parking.

- Avoid traffic and pollution as possible from site.

- The site layout should allow for wind protection and solar access in winter and adequate sun protection and ventilation in summer.

A land with total 750 square meters area (category C) was 
selected to design the multi-function apartment on it and it has the following regulations: front and back setbacks 4 meters, side setbacks 3 meters, and percentage build up area $51 \%$ of the total land area.

\subsubsection{Apartment areas, capacity, and adaptation}

The multi-function apartment has a total area equal to 75 square meters, start with two adults and grow with them three children until they reach six years old.

\subsubsection{Energy demand}

The primary function of a building envelope is to protect its occupants from heat, cold, rain, and to provide thermal and visual comfort for work and leisure. In order to achieve comfort conditions, it is almost essential to provide energy consuming space conditioning and lighting devices (Roaf, 2001). The energy usage of a building can be improved by energy demand reduction, energy efficiency and use of renewable sources of energy. Hence, to reduce energy demand, we need to reduce cooling, heating load. The strategy used to reduce energy needed is by reducing the apartment areal volume, and thus the needed energy will obtain the family need.

\subsubsection{Technology used (form and material)}

Form, The apartment contain portable concrete cube to fit different needs of various users, to reduce the initial cost of construction and reducing the internal volume depending on the number of occupancies in building.

Material, Material selection criteria is based on resource efficiency, indoor air quality, energy efficiency, availability and finally its affordability. Building materials are mostly made from naturally available materials like clay, bricks/ blocks, sand or biomass. Proper selection of building materials would help to conserve these natural resources.

In proposed design, used industrial waste-based bricks/ blocks for non-structural or infill wall system. Water-based acrylics was used for paints and using acrylics, silicones acrylic sealants for interior use. The design avoided using products using asbestos and CFC and minimize the use of metallic surfaces and metallic pipes, fitting, and fixtures.

Pre-fabricated reinforced concrete was used for all exterior walls and for slab between floors, its properties as follows, Table 2 and tTable 3:

Table 2. Pre-fabricated Reinforced Concrete exterior Wall Layers.

Outside

\begin{tabular}{|l|l|l|l|l|}
\hline Layer name & $\begin{array}{l}\text { Width } \\
(\mathrm{mm})\end{array}$ & $\begin{array}{l}\text { Density } \\
(\mathrm{kg} / \mathrm{m} 2)\end{array}$ & $\begin{array}{l}\text { Specific heat } \\
(\mathrm{J} / \mathrm{kg} . \mathrm{K})\end{array}$ & Conductivity (W/m.K) \\
\hline Jotashield Thermo coating & 10.0 & 0.00088 & 0.1055 & Jotashield Thermo coating \\
\hline Plaster & 30.0 & 1200.0 & 840.000 & 0.520 \\
\hline $\begin{array}{l}\text { Pre-fabricated Reinforced } \\
\text { Concrete }\end{array}$ & 100.0 & 2300.0 & 656.900 & 0.753 \\
$\begin{array}{l}\text { Thermal insulation (with } \\
\text { Low K) }\end{array}$ & 60.0 & 1300.0 & 1255.000 & 0.138 \\
\hline $\begin{array}{l}\text { Air Gap } \\
\text { Lightweight special block }\end{array}$ & 40.0 & 740.0 & 1088.000 & 5.560 \\
\hline
\end{tabular}

Inside

Table 3. Slab between Floors Layers.

Outside

\begin{tabular}{|l|l|l|l|l}
\hline Layer name & $\begin{array}{l}\text { Width } \\
(\mathrm{mm})\end{array}$ & $\begin{array}{l}\text { Density } \\
(\mathrm{kg} / \mathrm{m} 2)\end{array}$ & $\begin{array}{l}\text { Specific heat } \\
(\mathrm{J} / \mathrm{kg} . \mathrm{K})\end{array}$ & Conductivity $(\mathrm{W} / \mathrm{m} . \mathrm{K})$ \\
\hline Tile, Terracotta & 30.0 & 1700.0 & 840.000 & 0.810 \\
\hline Cement Mortar & 20.0 & 1650.0 & 920.000 & 0.720 \\
\hline Sand fill & 100.0 & 1600.0 & 753.100 & 0.335 \\
\hline Reinforced Concrete & 150.0 & 2300.0 & 656.900 & 0.753 \\
\hline Plaster & 10.0 & 1200.0 & 840.000 & 0.520 \\
\hline $\begin{array}{l}\text { Jotun Eco-Health Interior } \\
\text { Paints }\end{array}$ & 5.0 & 1250.0 & 1088.000 & 0.431 \\
\hline
\end{tabular}

Inside 
International Journal of Engineering Research and Technology. ISSN 0974-3154, Volume 13, Number 9 (2020), pp. 2115-2123

(C) International Research Publication House. https://dx.doi.org/10.37624/IJERT/13.9.2020.2115-2123

\subsubsection{The design (Layouts)}

\subsubsection{Phase I}

Total area of the apartment in is 47.5 square meters with 12.25 square meters for balcony contain one gestlliving room, Kitchen, 1 bedroom and 2 bathrooms, in this phase this apartment fits for a couple and one child, Figure 14.

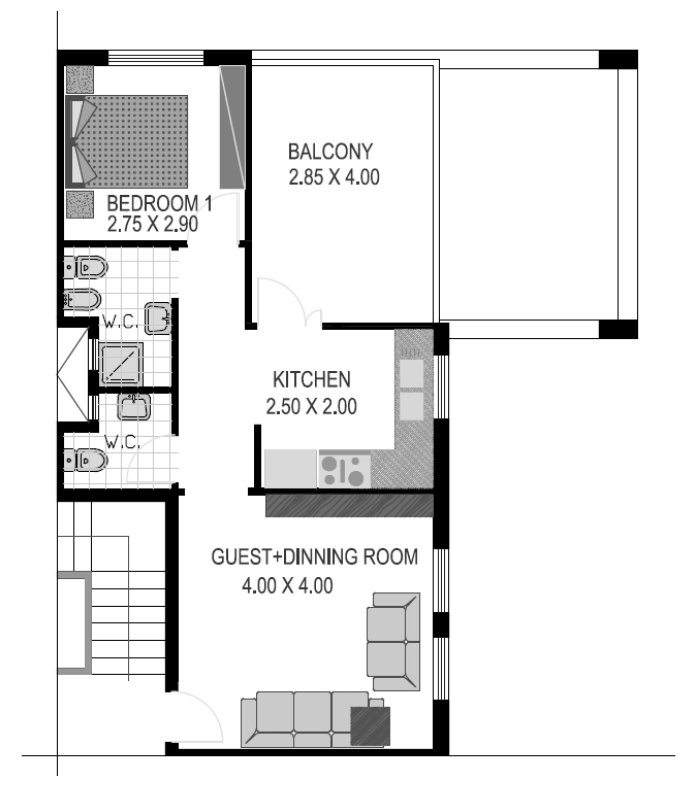

Figure 14. Plan Layout (phase I).

\subsubsection{Phase II}

Total area of the apartment is 60 square meters with 12.25 square meters for balcony contain one gestlliving room, Kitchen, 2 bedrooms and 2 bathrooms, in this phase this apartment fits for a couple with two children and still have ability of expansion, Figure 15.

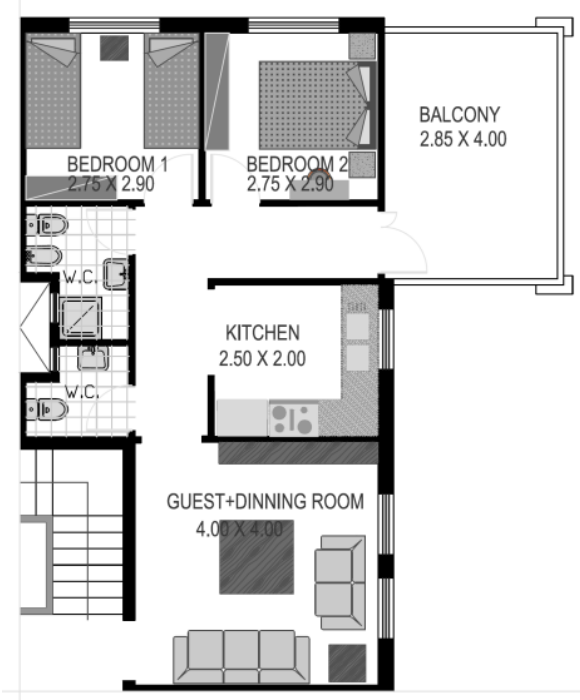

Figure 15. Plan Layout (phase II).

\subsubsection{Phase III}

Total area of the apartment is 74.5 Square meters with 12.25 square meters for balcony contain one gestlliving room, Kitchen, 3 bedrooms and 3 bathrooms; this apartment fits for a couple with four children, Figure 16.

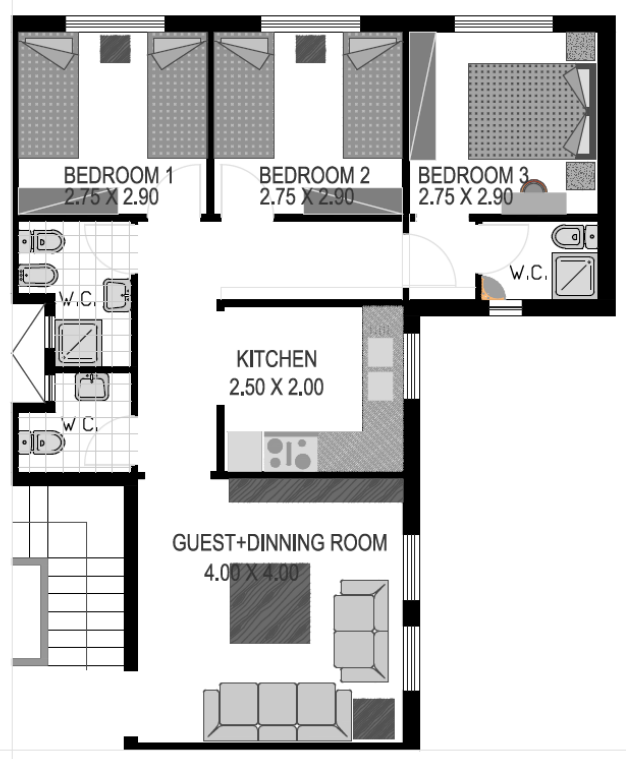

Figure 16. Plan Layout (phase III).

\section{ANALYSIS AND RESULTS}

The study aims to create a model (building layout) of an intelligent multi-function apartment, and evaluated it with the current apartments that can be found on market. The parameters studied include (apartment type, apartment capacity, apartment adaptation overtime, prices, energy demand and uses of different building technology), and the results come as follows:

\subsection{Apartment adaptation}

The design provide various plan layout with different areas up to 75 square meters grow and adopt with family needs, and by this grow the initial cost will reduce, which enable Jordanians to own homes as a first step to a minimal and streamlined life.

\subsection{Energy demand}

By studying the thermal behavior (heat gain/loss) of a typical type II, apartment and multi-function apartment with previous selected material building in one of the hottest days of summer (16 of May) in Amman city calculated by computer software (Ecotect-Autodesk) the results are, Figure 17: 


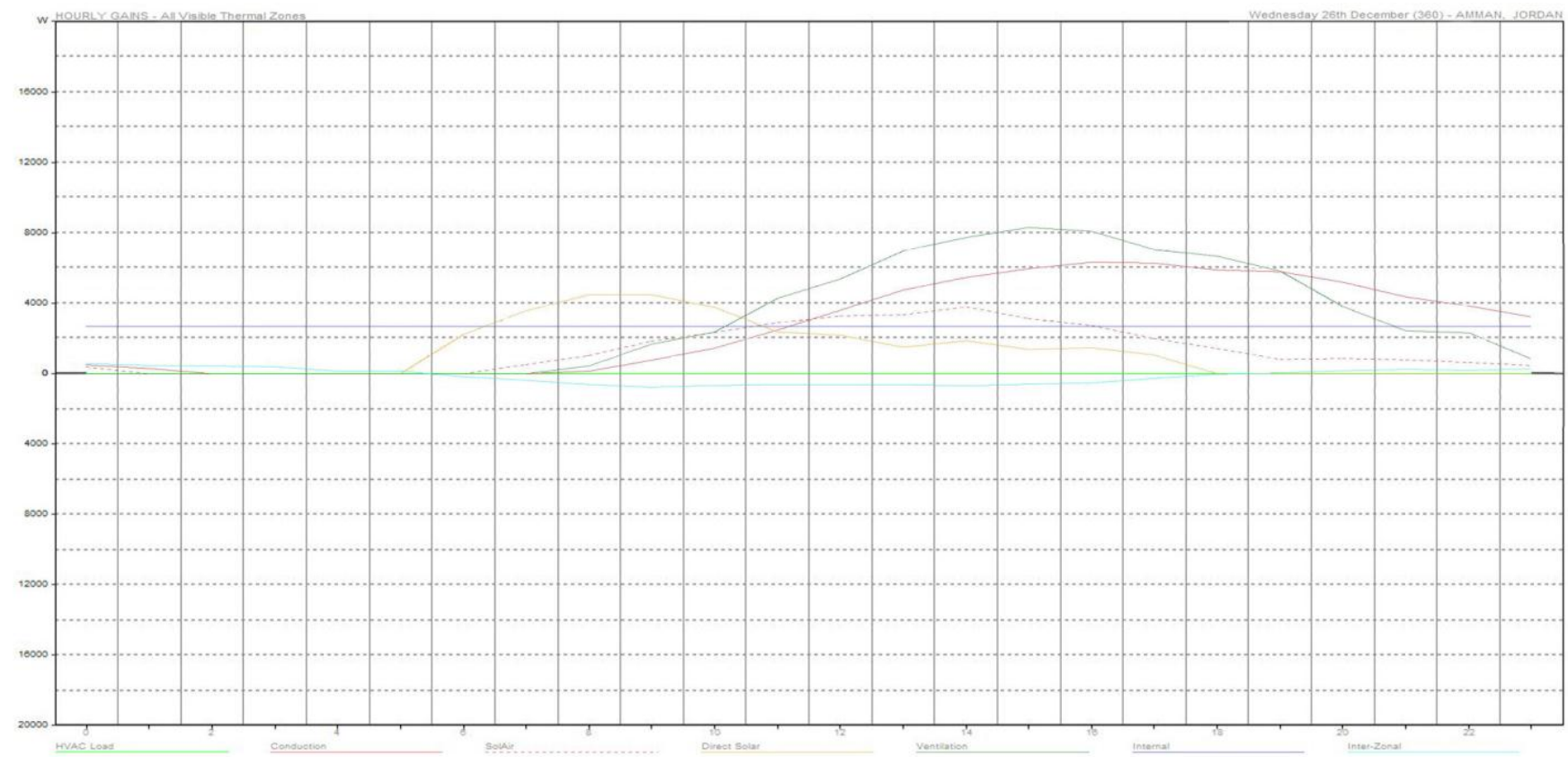

Figure 17. Thermal Mass-Heat Gain Loss Graph.

To show one of the benefits, the solid red line was taken as an example as it represents conduction-gains/losses that occur through the fabric of the building itself. In the typical apartment the line has gained a large amount of energy in a very short period and in the evening equal it losses it very quickly and this shows deficiency in the material (fast transfer of energy between indoor and outdoor media). After changing the different layers composing the exterior wall a material was found that can gain energy more efficiently and lose it slowly. The overheating problem in the summer was solved by chosen materials with an acceptable range of energy gain according to the comfort zone and keeping it in the same level.

\subsection{Building technology}

By using and improve building form and material to retain energy and reduces the heat losses.

\subsection{Apartment price}

Initial cost of the of 20,000 - 25,000 JD and 5,000 JD for prefabricated extension units, with two extension total price will reach 35,000 JD

4.5. Main comparison schedule, as seen in Table 4:

Table 4. Main Components Comparison Schedule

\section{Typical apartment (type II) Multi-function apartment}

\begin{tabular}{|c|c|c|}
\hline Average Apartment Area & $90-150$ square meters & $50-75$ square meters \\
\hline Apartment Capacity & 1 family $\backslash$ avg. 5 members & 1 family $\backslash$ avg. 5 members \\
\hline Apartment Adaptation & $\begin{array}{l}\text { No development availability } \\
\text { after construction period }\end{array}$ & Development per family need \\
\hline Price (average) & $50,000-100,000 \mathrm{JD}$ & $\begin{array}{l}20,000 \text { JD initial cost and } 10,000 \\
\text { JD for expansion }\end{array}$ \\
\hline Energy demand heating and cooling & $\begin{array}{l}\text { Per study heat gain -loss } 9000 \\
\text { Watt for one day } 16 \text { May till } \\
\text { 18:00 }\end{array}$ & $\begin{array}{l}\text { Per study heat gain -loss reduced } \\
\text { to } 4000 \text { Watt for one day } 16 \text { May } \\
\text { till } 18: 00\end{array}$ \\
\hline $\begin{array}{l}\text { Technology used (building form, } \\
\text { material) }\end{array}$ & $\begin{array}{l}\text { Current apartment shows lack } \\
\text { in the aesthetic and } \\
\text { technological aspects }\end{array}$ & $\begin{array}{l}\text { Use of different technology in } \\
\text { material and energy and } \\
\text { adaptation }\end{array}$ \\
\hline
\end{tabular}


International Journal of Engineering Research and Technology. ISSN 0974-3154, Volume 13, Number 9 (2020), pp. 2115-2123

(C) International Research Publication House. https://dx.doi.org/10.37624/IJERT/13.9.2020.2115-2123

\section{CONCLUSIONS AND RECOMMENDATIONS}

When thinking about the design and build of new homes now we need to think about whether they will meet the needs and lifestyles of the future. Perhaps people need more room in their homes now - to play interactive computer games safely, or so that everyone can find a quiet and peaceful place to rest. Or perhaps there is a valid reason why the homes getting built today fall short of existing space standards - perhaps people no longer feel the need for bedside tables or chairs in their bedrooms, or to eat as a household at a dining table. To provide a genuine choice for people thinking about buying or renting a home, new homes need to reflect the needs and concerns of contemporary society. Improving the quality of new homes will be a joint venture for house builders, architects, and planners. Here are some initial recommendations stemming from our research.

1. Improve marketing information: Estate agents and housing providers should display clearly the floor area of homes on all marketing material. They should also show floor plans with furniture and other items illustrated, so that consumers can better understand what space means to them and their lifestyles.

2. Publish data about the size and quality of new homes: To ensure greater transparency in the market place, developers should publish this relevant information relating to the quality of new homes.

3. Make Energy Performance Certificates mandatory at point of market rather than after contracts have been signed: Energy Performance Certificates need to be available and explained for every home being marketed - not simply requested and provided only after contracts have been signed and people are about to move in.

4. Work with the house building industry to produce an industry-wide voluntary agreement that house builders publish data about the size and quality of new homes. The Department for Communities and Local Government and the Homes and Communities Agency could facilitate this work to ensure data is published on a regular basis, in a way that is both transparent and does not add an unnecessary regulatory burden upon businesses.

\section{ACKNOWLEDGEMENT}

I would like to express my sincere gratitude to Arch. Anas Hoor and Arch. Abdalrahman Kattab to their assistance in completing this work.

\section{REFERENCES}

Al-Asad, M. 2004. Apartment Living: Urban Crossroads \#11. Center for the Study of the Built Enviornment, Ammn, Jordan. https://www.csbe.org/apartment-building

Al Momani, H. and Ali, H. 2008. Sick Building Syndrome in Apartment Buildings in Jordan. Jordan Journal of Civil Engineering, 2(4), 391-403. https://jjce.just.edu.jo/issues/paper.php?p=65.pdf

Bergman, D. 2020. Sustainable Design: A Critical Guide (Architecture Briefs). London: Princeton Architectural Press. ISBN: 978-1568989419

Roaf, S. 2001. Ecohouse: A Design Guide. New York: Architecture Press. ISBN-13: 978-0750649049

Beithou, N., Abdellatif, Y., Al-Taani, M. and Abu-Hilal, M. 2011. Proposed Energy Saving Techniques for Multi-Apartment Buildings in Jordan. International Journal of Thermal and Environmental Engineering, 3(1), 27-36. DOI: 10.5383/ijtee.03.01.005

Crook, L. 2016. JAAK Reconfigures Hong Kong Apartment with Space-saving Cabinetry. Dezeen Magazine. Accessed August 2020. https://www.dezeen.com/2016/12/22/jaak-reconfigures-hong-kongchina-apartment-space-saving-furniture/

Friedman, A. 2006. The Grow Home. Monteral: McGill-Queen's University Press.

ISBN: 978-0773522046

Jaber, J. 2002. Prospects of Energy Savings in Residential Space Heating. Energy and Buildings, 34(4), 311-319. https://doi.org/10.1016/S0378-7788(01)00118-9

Lin, Z. 2011. Nakagin Capsule Tower: Revisiting the Future of the Recent Past. Journal of Architectural Education, 65(1),13-32. DOI: $10.2307 / 41319216$

Morris, A. 2019. Vertical Garden and Sleeping Pod Feature in Small Madrid Apartment. Dezeen Magazine. Accessed August 2020. https://www.dezeen.com/2019/04/16/husos-arquitectos-madridinteriors/

Nothingam, S. 2014. Small Apartment in Tel Aviv Gets a Trendy Modern Makeover. Decoist Magazine. Accessed August 2020. https://www.decoist.com/2014-03-03/small-apartment-renovationtel-aviv/

The Department of Statistics (DoS). 2018. Jordan Statistical Yearbook.

http://dosweb.dos.gov.jo/databank/yearbook/YearBook_2018.pdf

Weinzettel, J. and Others. 2011. Footprint Family Technical Report: Integration into MRIO Model, Godalming UK: One Planet Economy Network. http://www.oneplaneteconomynetwork.org

World Bank Group. 2018. Jordan Housing Sector Review: Project P158331. documents.worldbank.org 